\title{
Література:
}

1. Якимов И. Н. Практическое руководство к расследованию преступлений. - М., 1924.

2. Колесниченко А.Н. Научные и правовые основы расследования отдельных видов преступений. Автрореф. дис.... д-ра юрид. наук: 12.00.09. - Харьков: Юрид. институт, 1967. - 28 с.

3. У Львові викрито діяльність «ботоферм», які використовувалися для викрадення персональних даних працівників СБУ. URL: https://www.gp.gov.ua/ua/news?_m=publications\&_c=view\&_t=rec\&id $=293792$

4. Ткачова О.В., Науменко К.В. Кримінологічна характеристика кіберзлочинця. Юридичний науковий журнал. 2018. №2. С. 200-204.

5. Романюк Б., Гавловський В., Гуцалюк М., Бутузов В. Виявлення та розслідування злочинів, що вчиняються у сфері інформаційних технологій: наук.-практ. посібник / за заг. ред. Я. Кондратьєва. К.: Вид. А.В. Паливода, 2004. - 144c.

6. Найдьон Я. Поняття та класифікація віртуальних слідів кіберзлочинів. Підприємництво, господарство і право. 2019. № 5. С. 304-307.

7. Волеводз А.Г. Противодействие компьютерным преступлениям: правовые основы международного сотрудничества. Москва: ООО «Издательство «Юрлитинформ», 2001. 496 с.

DOI https://doi.org/10.30525/978-9934-26-074-2-65

\section{ЗАБЕЗПЕЧЕННЯ ПРАВ ПОТЕРПІЛОГО У КРИМІНАЛЬНОМУ ПРОВАДЖЕННІ: АКТУАЛЬНІ ПРОБЛЕМИ}

\author{
Мазур М. Р. \\ кандидат юридичних наук, \\ дочент кафедри кримінального прочесу та криміналістики \\ юридичного факультету \\ Львівського національного університету імені Івана Франка \\ м. Львів, Україна
}

У 2012 році в Україні було ухвалено новий Кримінальний процесуальний кодекс (КПК України) [1]. Незважаючи на схвальну оцінку даного законодавчого акту як вітчизняними науковцями і практиками, так і міжнародною спільнотою, досі низка його інститутів потребує 
суттєвого вдосконалення. Зокрема, йдеться про інститут потерпілого у кримінальному провадженні.

Приділивши суттєву увагу правам підозрюваних, законодавець відсунув права потерпілих на другий план. Хоча у кодексі наведено значний перелік прав потерпілого, часто на практиці ці права залишаються без достатніх гарантій [2].

В Україні, як і більшості пострадянських країн, досі діє так звана «ретрибутивна система», основною метою якої є покарання особи, що вчинила кримінальне правопорушення. Натомість мало уваги приділяється захисту потерпілих, які потребують фізичної, фінансової, юридичної підтримки, а також психологічної реабілітації [3].

Українське законодавство містить широкий перелік прав потерпілого для активної участі в розслідуванні злочину та подальшому судовому процесі. Проте на практиці багато з них залишаються декларативними.

Відповідно до статті 55 КПК України, потерпілим у кримінальному провадженні може бути фізична особа, якій кримінальним правопорушенням завдано моральної, фізичної або майнової шкоди, а також юридична особа, якій кримінальним правопорушенням завдано майнової шкоди.

Права і обов'язки потерпілого виникають в особи з моменту подання заяви про вчинення щодо неї кримінального правопорушення або заяви про залучення iï до провадження як потерпілого.

Протягом кримінального провадження потерпілий має право:

1) бути повідомленим про свої права та обов'язки, передбачені КПК України;

2) знати сутність підозри та обвинувачення, бути повідомленим про обрання, зміну чи скасування щодо підозрюваного, обвинуваченого заходів забезпечення кримінального провадження та закінчення досудового розслідування;

3) подавати докази слідчому, прокурору, слідчому судді, суду;

4) заявляти відводи та клопотання;

5) за наявності відповідних підстав - на забезпечення безпеки щодо себе, близьких родичів чи членів своєї сім'ї, майна та житла;

6) брати участь у слідчих (розшукових) та інших процесуальних діях; брати участь у судовому провадженні;

7) давати пояснення, показання або відмовитися їх давати;

8) оскаржувати рішення, дії чи бездіяльність слідчого, прокурора, слідчого судді, суду;

9) мати представника (адвоката) та в будь-який момент кримінального провадження відмовитися від його послуг; 
10) давати пояснення, показання рідною або іншою мовою, якою він вільно володіє, безоплатно за рахунок держави користуватися послугами перекладача в разі, якщо він не володіє державною мовою чи мовою, якою ведеться кримінальне провадження;

11) на відшкодування завданої кримінальним правопорушенням шкоди в порядку, передбаченому законом;

12) знайомитися 3 матеріалами, які безпосередньо стосуються вчиненого щодо нього кримінального правопорушення, а також знайомитися 3 матеріалами кримінального провадження, які безпосередньо стосуються вчиненого щодо нього кримінального правопорушення, у випадку закриття цього провадження;

13) застосовувати 3 додержанням вимог закону технічні засоби при проведенні процесуальних дій, в яких він бере участь;

14) одержувати копії процесуальних документів та письмові повідомлення;

15) користуватися іншими правами, передбаченими КПК України.

На всіх стадіях кримінального провадження потерпілий має право примиритися 3 підозрюваним, обвинуваченим i укласти угоду про примирення.

3 системного аналізу чинного законодавства та практики його застосування [4], в контексті забезпечення прав потерпілих у кримінальному провадженні, можемо виділити наступні проблеми.

По-перше, це стосується моменту набуття статусу потерпілого. Хоча у КПК України й проголошено, що потерпілий набуває своїх прав 3 моменту подання заяви/повідомлення про вчинення кримінального правопорушення, більшість слідчих і прокурорів вважають цим моментом вручення пам'ятки про права потерпілого. Крім того, непоодинокими $є$ випадки винесення постанов про визнання потерпілим (практика КПК України 1960 р.), що не передбачено чинним КПК України.

По-друге, інформування потерпілого про його права та хід розслідування відбувається здебільшого формально. Така процедура як вручення пам'ятки про права потерпілого, на практиці, часто здійснюється без належного їх роз'яснення.

По-третє, існують складнощі з реалізацією прав потерпілого пов'язані 3 більш обмеженими (порівняно із підозрюваними/обвинуваченими) можливостями залучення адвокатів, зокрема безоплатної правової допомоги. Потерпілі не є окремими суб'єктами безоплатної правової допомоги, а тому самотужки не завжди спроможні повною мірою реалізувати свої права у кримінальному провадженні [4]. 
По-четверте, відсутність системного підходу до захисту потерпілих. Незважаючи на широкий перелік відповідних способів (таких як фізична охорона, зміна анкетних даних) рівень їх застосування дуже низький. Причинами цього $\epsilon$, зокрема, недостатньо чіткі законодавчі механізми, неналежне матеріально-технічне забезпечення правоохоронних органів $\mathrm{i}$ судів, тощо.

По-п'яте, сьогодні можемо констатувати критичну ситуацію 3 відшкодуванням (компенсацією) шкоди завданої потерпілому кримінальним правопорушенням. Серед усіх прав потерпілих право на відшкодування шкоди забезпечено в Україні чи не найгірше. Крім того, досі не вироблено державного механізму, який гарантував би компенсацію такої шкоди потерпілим [4].

Наявна практика визначення розмірів моральної шкоди $є$ також далекою від досконалості. Часто розміри компенсацій, які присуджуються за рішенням суду, є надто низькими і не відповідають важливості цінностей, на які спрямовані кримінальні правопорушення. У першу чергу, йдеться про посягання на життя та здоров'я потерпілого.

Сьогодні все більшої популярності набуває так званий victim oriented approach (підхід, орієнтований на потерпілого). У СС його почали широко використовувати після ухвалення у 2012 році Директиви 2012/29/EU про встановлення мінімальних стандартів щодо прав, підтримки та захисту потерпілих від злочину [5]. Згідно victim oriented approach, особлива увага звертається на психологічний, фізичний, матеріальний та юридичний захист потерпілих від кримінального правопорушення. Видається дуже доречним, наближення українського кримінального процесуального законодавства до стандартів даного підходу, тим самим надаючи потерпілому, його правам та законним інтересам більш пріоритетного місця у кримінальному провадженні.

\section{Література:}

1. Кримінальний процесуальний кодекс України від 13 квітня 2012 p. URL: https://zakon.rada.gov.ua/laws/card/4651-17 (дата звернення: 10.04.2021).

2. Крісткова В., Човган В. Чому в Україні жертви злочинів страждають двічі. Украӥнська правда. 2019. URL: http:// https://life.pravda.com.ua/columns/2019/03/27/236234/ (дата звернення: 10.04.2021).

3. Не помста злочинцеві, а підтримка жертви. Як в Україні захищають потерпілих від насильницьких злочинів? URL: https://www.radiosvoboda.org/a/prava-poterpilyh-vid-nasylnytskykhzlochyniv/31171524.html (дата звернення: 30.03.2021). 
4. Права потерпілих від насильницьких злочинів в Україні: міжнародні стандарти та національні практики / Орлеан А., Павлюковець Т., Крапивін Є., Лотюк Д., Човган В. Київ: «Видавничий дім «Артек», 2020. 206 c.

5. Directive 2012/29/eu of 25 October 2012 establishing minimum standards on the rights, support and protection of victims of crime. URL: https://eur-lex.europa.eu/legalcontent/EN/TXT/?qid=142192513161 4\&uri=CELEX:32012L0029 (last accessed: 30/03/2021).

DOI https://doi.org/10.30525/978-9934-26-074-2-66

\title{
ЗНАЧЕННЯ ЗАСАДИ ПРЕЗУМПЩІЇ НЕВИНУВАТОСТІ ТА ЗАБЕЗПЕЧЕННЯ ДОВЕДЕНОСТІ ВИНИ У КРИМІНАЛЬНОМУ ПРОВАДЖЕННІ
}

\author{
Парасюк М.В. \\ кандидат юридичних наук, дочент, \\ доцент кафедри иивільного права та процесу \\ Інституту права, психології та інноваційної освіти \\ Національного університету «Львівська політехніка» \\ м. Львів, Украӥна
}

Відповідно до п. 3 ч. 3 ст. 129 Конституції України, ст. 17 КПК України однією з засад кримінального судочинства презумпція невинуватості та забезпечення доведеності вини. У юридичній літературі відмічається, що реалізація конституційної вимоги щодо забезпечення вини можлива за умови дотримання таких вимог : 1) вимога імперативного характеру щодо «забезпечення», виявом якої в кримінальному процесі $є$ його публічність; 2) вимога щодо дотримання презумпції невинуватості як конституційної гарантії прав і свобод осіб, залучених до кримінального процесу; 3) доведеність вини як результат доказування, що врівноважує публічні та приватні інтереси суб'єктів кримінального процесу.

Саме унеможливлення притягнення до відповідальності невинних осіб являється основною метою принципу презумпції невинуватості, яка в свою чергу є однією із основних засад дотримання прав людини в демократичному суспільстві [1, С. 114].

Відповідно до п. 2 ч. 1 ст. 91, ч. 1 ст. 92 КПК України обов'язок доведення вини підозрюваного, обвинуваченого покладається на слідчого, прокурора. «Зміст цього обов’язку полягає, - як слушно зазначає Л. 